Article

\title{
Techno-Economic Analysis of Extruding-Expelling of Soybeans to Produce Oil and Meal
}

\author{
Ming-Hsun Cheng $(\mathbb{D}$ and Kurt A. Rosentrater *(D) \\ Department of Agricultural and Biosystems Engineering, Iowa State University, Ames, IA 50011, USA; \\ minghsun@iastate.edu \\ * Correspondence: karosent@iastate.edu
}

Received: 1 March 2019; Accepted: 23 April 2019; Published: 26 April 2019

\begin{abstract}
Mechanical expelling (pressing) is a common and developed technique used to separate soybean oil from soybean protein and fiber. Due to the relatively higher oil content in the expelled meal compared to solvent-extracted soybean meal, the mechanical process is often used for specific purposes in industry, such as targeted livestock feed applications. For improving oil recovery and profits, two-stage mechanical process combining extrusion before the expelling process has been introduced and adapted by industrial applications. To examine the viability of this improved two-stage extruding-expelling process, techno-economic analysis was performed by using SuperPro Designer for simulation of the soybean extruding-expelling process. Soybean oil yield increases to over $70 \%$ compared to the conventional single-step expelling process with $60 \%$. Soybean oil and soybean meal contributed about $25 \%$ and $75 \%$ of total revenues, respectively. Through fluctuations in economic conditions, soybean meal plays an important role in earning profits, making the whole mechanical process profitable. According to the sensitivity analysis, the sale of soybean meal is one of the driving forces for the mechanical expelling process, especially in large industrial scales.
\end{abstract}

Keywords: soybean oil; soybean meal; extruding-expelling process; techno-economic analysis; profits

\section{Introduction}

Soybean is one of the main oilseed crops in the world, and production in the USA has increased over $50 \%$ to about 3.93 billion bushels since the 1980s [1]. Iowa is one of the major states producing soybean [2]. The value of soybeans includes good quality oil and digestible proteins and minerals [3-5]. Soybean oil is one of the main products from soy processing operations. It is also one of the main oils used for applications in the food industry and industrial applications, such as such as biodiesel and bio lubricant conversion [6,7]. Soybean meal is also an important product from the oil removal process; soy meal is commonly used as a protein source for many livestock diets due to its high protein level, balanced amino acid profile, and variety of minerals and vitamins [8].

Mechanical pressing and solvent extraction are the two primary methods of oil removal used in soybean processing. The mechanical process, with hydraulic pressing and continuous screw pressing techniques, was used before the development of solvent extraction [9]. Because higher oil recovery and efficiency is associated with solvent extraction, mechanical expelling has declined in popularity, having been replaced by the solvent extraction techniques. Subsequently, it has been determined that organic solvents used in extraction (e.g., hexane) can cause human health, safety and environmental contamination $[10,11]$. Therefore, a chemical free process, known as the expelling/pressing approach, is still applied when producing oil for food and industrial purposes. Also, soybean meal produced from processing is still used predominantly for animal feeds [9].

Typically, cracking and cooking are used to reduce crop size and disrupt spherosome tissues first, before pressure is applied to squeeze oil out of the matrix [12]. For increasing oil recovery, 
several passes of pressing are needed. However, multiple passes lead to excessive heating, resulting in the darkening and deterioration of oil. Nelson et al. [9] introduced an extruding-expelling process (Figure 1), where an extrusion process is performed before the expelling process. The cooking process is exempt from processing because the heat is generated from the friction among soybeans within extruders. This technique not only simplifies the tissue rupturing and heating processes but mitigates the darkening oil color from overheating and increases the oil recovery to over $70 \%$. This approach is also used in the soybean oil expelling industry.

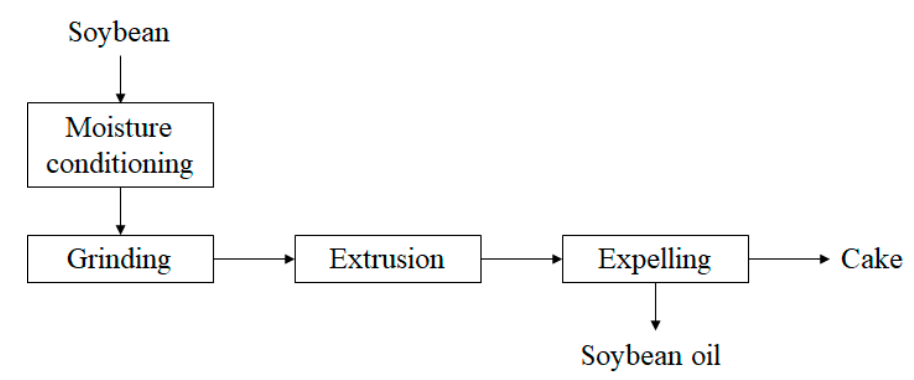

Figure 1. Schematic flow chart of typical extruding-expelling process.

To improve oil recovery from the expelling process, researchers perform different pretreatment strategies to expelling process, such as using different screwing speeds, and bean crushing processes [13-15]. However, economic feasibility is another critical factor for the mechanical expelling technique due to industrial and commercial applications. The economic analysis of oil extraction is generally included in techno-economic analysis of biodiesel production, because oil extraction is regarded as a part of the pretreatment of biodiesel conversion [16-18]. Moreover, previous studies on the economics and cost of mechanical pressing for plant oil production are mainly for small-scale on-farm operations. The unit fixed cost of mechanical pressing ranges from 0.01 to $0.42 \$ / \mathrm{kg}$ oil seed; the unit oil production cost is from 0.66 to $2.58 \$ / \mathrm{kg}$ oil. The wide range of fixed and production costs are derived from different oil crops, plant locations, machine and material suppliers, and analysis assumptions [19-24]. Also, different methodologies of economic modeling are conducted for vegetable oil use in biodiesel conversion [25-27]. Unfortunately, very few studies have examined the economics of oil removal from soybeans, especially for industry-scale mechanical expelling.

This study focused on the extruding-expelling process to produce crude soybean oil (degummed). The objective of this study was to construct a techno-economic simulation model. Specifically, this study examined the required capital expenditures, operating costs, sales revenues, and net profits. Additionally, historical data was collected and used to perform economic feasibility comparisons for different time periods from the 1980s to 2015. Due to the increasing demand for energy and food, many processing plants are planning to increase the capacity of their product lines. Therefore, the effects of different scales, from pilot scale to commercial scale were also assessed.

\section{Materials and Methods}

\subsection{Extruding-Expelling Process}

The extruding-expelling process was divided into crop handling, pre-extruding, expelling, degumming and oil recovery and soybean meal handling (Figure 2). In crop handling, soybean cleaning, drying, and grinding are included and the moisture content of soybeans was controlled to stay between $10-12 \%$. 


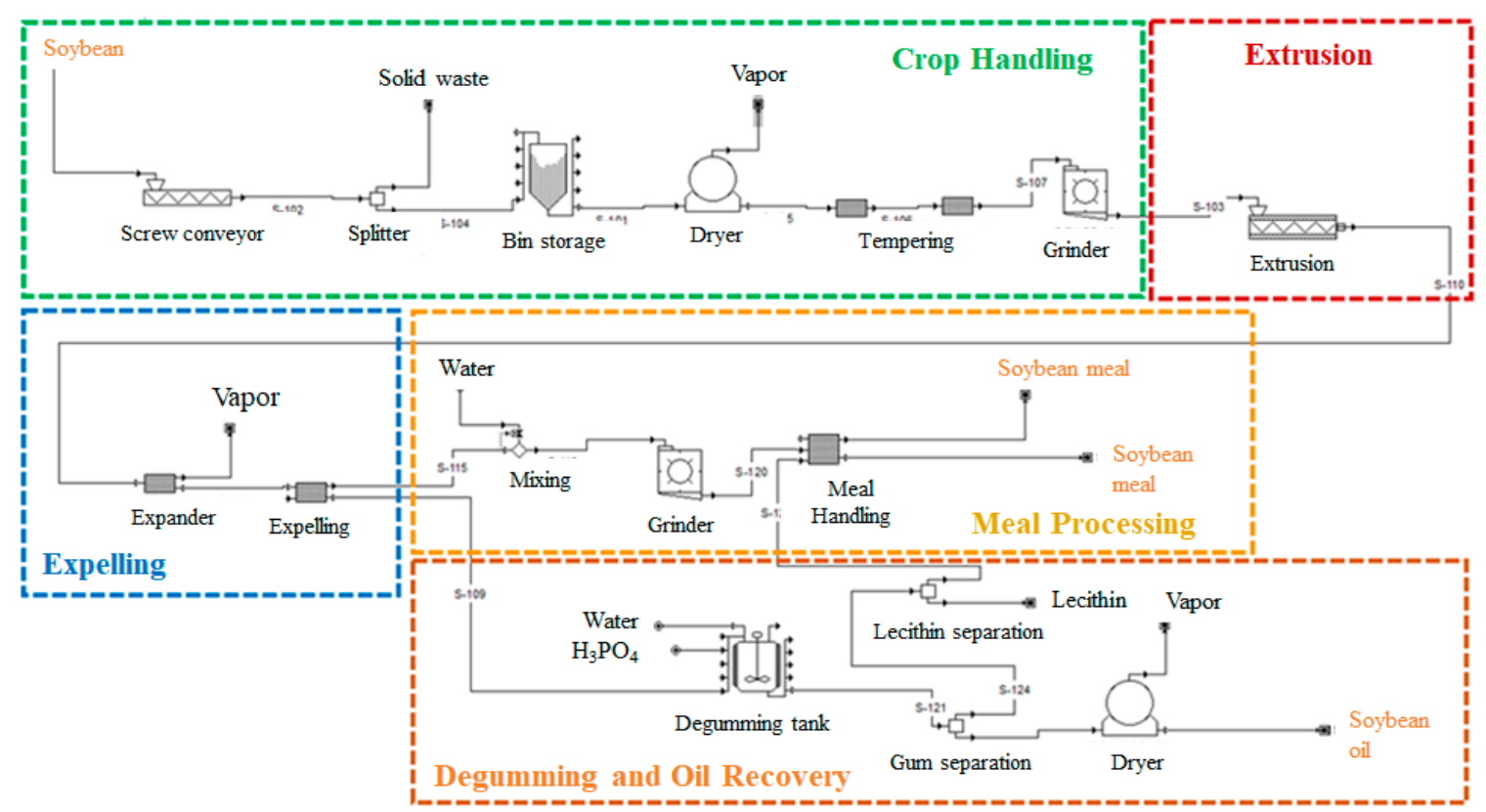

Figure 2. Flow diagram of soybean oil extruding-expelling TEA model.

The extrusion process follows crop handling. Different from typical conventional expelling processes, there was no need for cooking before expelling in the extruding-expelling process. During the extruding process, heat was generated during extruding because of friction among soybeans. The short retention time for soybeans staying in the extruder was sufficient to break spherosome tissue, and the output temperature of the extruder was over $130{ }^{\circ} \mathrm{C}$ [9]. After the extruding, the extrudate of coarse ground whole soybean was at $10 \%$ to $14 \%$ moisture levels having the semi-fluid like property and was then transported into the expeller continuously.

In the expelling process, pressure was used to squeeze oil out of the matrix. The expelled meal and oil are collected for the further meal handling and degumming processes respectively. Water degumming was used to remove the phospholipids; the water used was assumed to be at a 1:1 ratio to phospholipids by weight [28]. Otherwise, phosphoric acid was also used to remove small amounts of remaining water insoluble phospholipids. An $85 \%$ phosphoric acid solution was used, and the amount was $0.1-0.3 \%$ of oil [29]. After the degumming process, the oil was separated by a centrifuge and the degummed crude oil was obtained.

The soybean meal separated from the expelling process was collected and its moisture was kept below $10 \%$ for the convenience of storage. Soybean meal was the other product from the oil removal process; it was sold as a livestock feed ingredient.

\subsection{Computer Modeling and Simulation}

The techno-economic model of the extruding-expelling process for soybean oil production was developed in SuperPro Designer v9.0 (Intelligen, Inc., Scotch Plains, NJ, USA), based on mass balances amongst all unit operations. Economic parameters including fixed capital investment and operating costs which are basic for estimating gross profit, net profit, and the profitability of the whole processing venture [30].

The techno-economic model was built up by modifying the base economic model of soy oil biodiesel manufacturing by Haas et al., 2006 [17], which used a capacity of 192.28 million kg soybean input per annum, which was set as the baseline scale for our simulations which assessed a variety of operating capacities, including 30.77, 96.14, 672.99, 1257.53 and 2991.93 million $\mathrm{kg}$ soybean input per annum. The oil recovery efficiency was $72 \%$ which results in the annual soybean oil productivity corresponding to these 6 scales are 4.10,12.81, 25.62, 89.67, 175.56 and 398.67 million kg, respectively. Additionally, 
the different economic conditions from the 1980s to 2015 were also assessed according to the baseline scale. Historical data of operating costs were used as inputs for economic parameter estimations.

Fifteen-year processing plant service time, a construction of 30 months, startup of 4 months, tax of $35 \%$, a depreciation timeline of 10 years, and $5 \%$ salvage value of directed capital investments were set as the assumptions for the oil expelling plant in this study.

\subsection{Assumption and Data Collection}

\subsubsection{Fixed Costs}

The facility for each operating unit was the main resource of fixed costs. There are three main parts for fixed costs: total plant direct cost (TPDC), total plant indirect cost (TPIC) and contractor's fees and contingency (CFC). TPDC comes from the facility directly, including machine installation, piping connection, and electrical etc.; TPIC was fees associated with engineering and construction. The basic total plant cost (TPC) was the summation of TPDC and TPIC. Additionally, the contractor's fee was estimated by TPC; and the total direct fixed cost (DFC) was the summation of TPC and CFC. The working capital (WC) and startup cost (SC) are fees that ensure that the factory operates. Therefore, the total capital investment was the summation of DFC, WC, and SC. These costs are estimated using the facility purchase fee with certain multipliers shown in Table 1 [31].

Table 1. Direct cost and total capital investment multipliers.

\begin{tabular}{ccc}
\hline Cost Type & Category & Multiplier * \\
\hline & Purchase cost (PC) & $0.47 \times$ PC \\
Total Plant Direct Cost (TPDC) & Process piping & $0.68 \times$ PC \\
& Instrumentation & $0.26 \times$ PC \\
& Insulation & $0.08 \times$ PC \\
& Electrical & $0.11 \times$ PC \\
& Buildings & $0.18 \times$ PC \\
Total Plant Indirect Cost (TPIC) & Yard improvement & $0.10 \times$ PC \\
& Auxiliary facilities & $0.55 \times$ PC \\
\hline Total Plant Cost (TPC) & TPDC & $2.43 \times$ PC \\
\hline Contractor's fee and Contingency & Engineering & $0.30 \times$ TPDC \\
(CFC) & Construction & $0.35 \times$ TPDC \\
\hline Direct Fixed Cost (DFC) & TPIC & \\
\hline Working Capital (WC) & TPDC+TPIC & $0.06 \times$ TPC \\
\hline Total Capital & Contractor's fee & $0.08 \times$ TPC \\
\hline Startup Capital (SC) & Contingency & $0.15 \times$ DFC \\
\hline & TPC+CFC+WC+SC & $0.05 \times$ DFC \\
\hline
\end{tabular}

The purchase cost (PC) of each operating unit used for evaluating different investment years and plant capacities are estimated using the inflation index (Equation (1)) [32] and the six-tenths rule (Equation (2)) $[33,34]$ for each individual operation. $P_{c}$ was the inflation-adjusted price of equipment in the current year, $\mathrm{P}_{\mathrm{p}}$ indicates the cost of equipment in the previous year, and $\mathrm{I}_{\mathrm{c}}$ and $\mathrm{I}_{\mathrm{p}}$ are inflation index factors of current and previous years, respectively. For the six-tenths rule $(n=0.6), \mathrm{PC}_{\mathrm{p}}$ and $\mathrm{PC}_{\mathrm{c}}$ are facilities" purchase cost of predicted and basis scales; $q_{p}$ and $q_{c}$ indicate the facilities" capacity 
of predicted and basis scales, respectively, as well. The power value (n) was varied from $0.4-0.8$, depending on the various types of machines used.

$$
\begin{gathered}
P_{c}=P_{p} \times\left(\frac{I_{c}}{I_{p}}\right) \\
P C_{p}=P C_{c} \times\left(\frac{q_{p}}{q_{c}}\right)^{n}
\end{gathered}
$$

The PC was collected from the SuperPro Designer database, operational records of the Center for Crops Utilization, Iowa State University, and the Haas study (2006) [17]. The PC and the power use in this model are provided in Table 2.

Table 2. Facility prices and power values (n from Equation (2)) used for PC estimation for various processing capacities (baseline of 2015 price).

\begin{tabular}{ccc}
\hline & Power $(n)$ & PC of Baseline Scale (Thousands Dollar) \\
\hline Conveyor $^{*}$ & 0.6 & 9 \\
Storage bin $^{*}$ & 0.6 & 1400 \\
Drum dryer $^{+}$ & 0.4 & 68 \\
Grinder $^{+}$ & 0.6 & 171 \\
Extruder $^{\bullet}$ & 0.6 & 275 \\
Expeller $^{\bullet}$ & 0.6 & 1410 \\
Degumming tank $^{\bullet}$ & 0.49 & 67 \\
Centrifuge $^{\bullet}$ & 0.49 & 468 \\
Dryer for oil recovery $^{+}$ & 0.4 & 28 \\
Meal grinder $^{+}$ & 0.6 & 89 \\
Hull grinder $^{+}$ & 0.6 & 2590 \\
Meal processer $^{+}$ & 0.49 & 22 \\
\hline
\end{tabular}

Data adjusted according to $\left(^{*}\right)$ SuperPro Designer database [35]; (+) Haas (2006) [17]; and $(\bullet)$ Iowa State University CCUR pilot plant operational data.

\subsubsection{Operating Costs}

Operating costs for this model included materials, utilities, labor and facility-related costs. In the extruding-expelling process, the material cost was from soybeans, water and phosphoric acid. Utility costs include electricity, cooling water and steam, which are used to operate machines and as heating exchange agents. The main source of labor costs were agricultural machine operators and extraction workers. The operating cost inputs were an average price of each of 10 years (1980-2009); the average price of year 2010-2015 was performed as the current background for different capacities analyses. These operating cost inputs are listed in Table 3.

Table 3. Operating cost inputs for TEA modeling.

\begin{tabular}{cccccccc}
\hline & & Unit & 1980s & 1990s & 2000s & 2010s & Reference \\
\hline Materials & Soybean & $\$ / \mathrm{kg}$ & 0.228 & 0.217 & 0.255 & 0.438 & {$[36]$} \\
& Phosphoric acid & $\$ / \mathrm{kg}$ & 0.6 & 0.6 & 0.6 & 0.6 & {$[35]$} \\
Utilities & Water & $\$ / \mathrm{L}$ & 0.001 & 0.001 & 0.001 & 0.001 & {$[37]$} \\
& Electricity & $\$ / \mathrm{kwh}$ & 0.047 & 0.047 & 0.057 & 0.066 & {$[38]$} \\
Labor & Steam & $\$ / \mathrm{MT}$ & 12 & 12 & 12 & 12 & {$[35]$} \\
& Ag. machine operator & $\$ / \mathrm{hr}$ & 6.36 & 8.77 & 10.19 & 13.12 & {$[39]$} \\
& Extraction worker & $\$ / \mathrm{hr}$ & 9.30 & 13.72 & 17.69 & 20.86 & \\
\hline
\end{tabular}

For estimating the labor costs, an agricultural machine worker was assigned to crop and meal handling; extractor workers mainly deal with the extruding-expelling process and the degumming and oil recovery processes. The labor requirement for each machine was set between 0.1-1 (workers/unit/shift) for the baseline scale, which is listed in Table 4. A shift represents eight 
hours of working time. Additionally, a $0.2-0.25$ power relationship was applied to estimate the labor requirement for different operating capacities; this mathematical expression was similar to Equation (2) (Peters et al., 2011) [34]. Additionally, laboratory quality control and assurance labor costs were also considered, and were estimated at $15 \%$ of total labor cost (TLC) [25].

Table 4. Labor requirements for each operating facility (workers/unit/shift).

\begin{tabular}{ccccccc}
\hline & \multicolumn{7}{c}{ Soybean Annual Input (Million kg) } \\
\cline { 2 - 7 } & $\mathbf{3 0 . 7 7}$ & $\mathbf{9 6 . 1 4}$ & $\mathbf{1 9 2 . 2 8}$ & $\mathbf{6 7 2 . 9 9}$ & $\mathbf{1 5 2 7 . 5 3}$ & $\mathbf{2 9 9 1 . 9 3}$ \\
\hline Conveyor & 0.22 & 0.23 & 0.25 & 0.30 & 0.3 & 0.35 \\
Storage bin & 0.08 & 0.08 & 0.1 & 0.12 & 0.14 & 0.17 \\
Drum dryer & 1 & 1 & 1 & 1.26 & 1.46 & 1.82 \\
Grinder & 0.5 & 0.7 & 1 & 1.1 & 1.28 & 1.6 \\
Extruder & 0.88 & 0.95 & 1 & 1.1 & 1.16 & 1.24 \\
Expeller & 0.63 & 0.84 & 1 & 1.37 & 1.59 & 1.97 \\
Degumming tank & 0.64 & 0.84 & 1 & 1.35 & 1.6 & 1.96 \\
Centrifuge & 0.64 & 0.85 & 1 & 1.38 & 1.63 & 1.97 \\
Dryer for oil recovery & 0.8 & 0.8 & 0.8 & 0.8 & 0.8 & 0.8 \\
Meal grinder & 0.5 & 0.67 & 0.8 & 1.07 & 1.25 & 1.5 \\
Meal processer & 0.22 & 0.3 & 0.35 & 0.47 & 0.55 & 0.66 \\
\hline
\end{tabular}

\subsubsection{Revenues}

Soybean oil and soybean meal are the primary products of expelling processing. Sales prices from the 1980s to 2015 were compiled [36], averaged and are presented as the average price for each of 10 years (Table 5 ).

Table 5. Average sales prices of products from the soybean oil extruding-expelling process [36].

\begin{tabular}{ccccccc}
\hline & Unit & 1980s & 1990s & 2000s & 2010s & Citation \\
\hline Soybean oil & $\$ / \mathrm{kg}$ & 0.49 & 0.50 & 0.62 & 0.94 & {$[36]$} \\
Soybean meal & $\$ / \mathrm{kg}$ & 0.40 & 0.39 & 0.44 & 0.62 & {$[36]$} \\
\hline
\end{tabular}

After total capital investment was calculated, operating costs and total revenues, gross profits, gross margins, net profits, and return on investment (ROI) were calculated following Equation (3) to Equation (6) [31]. These parameters are critical indices for evaluating the economic feasibility of the whole extruding-expelling process.

$$
\begin{gathered}
\text { Gross Profit }=\text { Total Revenue }-(\text { Total operating cos } \mathrm{t}-\text { credits }) \\
\text { Gross Margin }(\%)=\frac{\text { Gross profit }}{\text { Revenue }} \times 100 \% \\
\text { Net Profit }=\text { Gross profit }- \text { Taxes }+ \text { Depreciation }
\end{gathered}
$$$$
\text { Return on Investment }(\%)=\frac{\text { Net profit }}{\text { Total capital investment }} \times 100 \%
$$

\subsection{Sensitivity Analysis}

Based on the TEA model, the sensitivity analysis was performed to examine the factors which had significant effects on the net profit of the process (accounting for fluctuating economic conditions). Changes in operating costs of $\pm 5 \%, \pm 15 \%$, and $\pm 25 \%$ included materials, labor, utilities, and facility-related costs, and revenues from soybean oil and soybean meal were also evaluated. The sensitivity analysis was based on the 2010 economic conditions. 
The calculations for net profit follow Equation (3) and Equation (5). To calculate the net profit change derived from each one of factors individually, the other factors were fixed, and the result was shown as percentage change.

\section{Results and Discussions}

\subsection{Total Capital Investment}

The purchase cost of equipment was the basis for fixed cost estimation. This reflects the required capital which was necessary to construct the operations necessary to produce the products at the beginning of the manufacturing venture. This cost will not change during plant service time. In addition to the hardware, the WC and SC are necessary to verify the whole process. Based on the assumptions for total capital investment, the results of different investment years and handling capacities are shown in Table 6.

Table 6. Capital investment estimations for extruding-expelling of soybean oil $(\$ 1000$, based upon 2015 prices).

\begin{tabular}{|c|c|c|c|c|c|c|c|c|c|c|}
\hline \multirow[b]{2}{*}{ Costs } & \multirow[b]{2}{*}{ Categories } & \multicolumn{4}{|c|}{$\begin{array}{l}\text { Time-Period Scenarios (Based on } 192.28 \\
\text { Million kg/year of Soybean Input) }\end{array}$} & \multicolumn{5}{|c|}{$\begin{array}{l}\text { Capacity-Based Scenarios (Million } \\
\text { kg/year of Soybean Input) }\end{array}$} \\
\hline & & $1980 \mathrm{~s}$ & $1990 \mathrm{~s}$ & $2000 \mathrm{~s}$ & $2010 \mathrm{~s}$ & 30.77 & 96.14 & 672.28 & 1257.53 & 2991.93 \\
\hline \multirow{10}{*}{$\begin{array}{l}\text { Total Plant Direct Cost } \\
\text { (TPDC) }\end{array}$} & Purchase cost (PC) & 3714 & 5326 & 6896 & 8218 & 3516 & 5406 & 14,445 & 20,284 & 21,322 \\
\hline & Installation & 1506 & 2161 & 2807 & 3342 & 1366 & 2296 & 6044 & 8371 & 8700 \\
\hline & Process piping & 2525 & 3622 & 4689 & 5588 & 2391 & 3676 & 9823 & 13,793 & 14,499 \\
\hline & Instrumentation & 996 & 1385 & 1793 & 2137 & 914 & 1406 & 3756 & 5274 & 5544 \\
\hline & Insulation & 297 & 426 & 552 & 657 & 281 & 433 & 1156 & 1623 & 1706 \\
\hline & Electrical & 409 & 586 & 759 & 904 & 387 & 595 & 1589 & 2231 & 2345 \\
\hline & Buildings & 668 & 959 & 1241 & 1479 & 633 & 973 & 2600 & 3651 & 3838 \\
\hline & Yard improvement & 371 & 533 & 690 & 822 & 352 & 541 & 1445 & 2028 & 2132 \\
\hline & Auxiliary facilities & 2043 & 2929 & 3793 & 4520 & 1934 & 2973 & 7945 & 11,156 & 11,727 \\
\hline & TPDC & 14,499 & 17,927 & 23,220 & 27,669 & 11,772 & 18,298 & 48,801 & 68,411 & 70,912 \\
\hline \multirow{3}{*}{$\begin{array}{l}\text { Total Plant Indirect Cost } \\
\text { (TPIC) }\end{array}$} & Engineering & 3750 & 5378 & 6966 & 8301 & 3532 & 5489 & 14,640 & 20,523 & 21,274 \\
\hline & Construction & 4375 & 6274 & 8127 & 9684 & 4120 & 6404 & 17,080 & 23,944 & 24,819 \\
\hline & TPIC & 8124 & 11,652 & 15,093 & 17,985 & 7652 & 11,894 & 31,721 & 44,467 & 46,093 \\
\hline Total Plant Cost (TPC) & TPDC+TPIC & 20,624 & 29,579 & 38,313 & 45,653 & 19,423 & 20,192 & 80,522 & 112,877 & 117,005 \\
\hline \multirow{2}{*}{$\begin{array}{l}\text { Contractor's fee and } \\
\text { Contingency (CFC) }\end{array}$} & Contractor's fee & 1237 & 1775 & 2299 & 2739 & 1165 & 1812 & 4831 & 6773 & 7020 \\
\hline & Contingency & 1650 & 2366 & 3065 & 3652 & 1554 & 2415 & 6442 & 9030 & 9360 \\
\hline Direct Fixed Cost (DFC) & $\mathrm{TPC}+\mathrm{CFC}$ & 23,551 & 33,720 & 43,676 & 52,044 & 22,143 & 34,419 & 91,795 & 128,680 & 133,385 \\
\hline \multirow{2}{*}{\multicolumn{2}{|c|}{$\begin{array}{l}\text { Working Capital (WC) } \\
\text { Startup Capital (SC) }\end{array}$}} & 3527 & 5508 & 6551 & 7807 & 3321 & 5163 & 13,769 & 19,302 & 20,008 \\
\hline & & 1176 & 1686 & 2184 & 2602 & 1107 & 1721 & 4590 & 6434 & 6669 \\
\hline Total Capital & $\mathrm{TPC}+\mathrm{CFC}+\mathrm{WC}+\mathrm{SC}$ & 28,213 & 40,464 & 52,412 & 62,453 & 26,571 & 41,602 & 110,154 & 154,416 & 160,062 \\
\hline
\end{tabular}

The baseline capacity of 192.28 million $\mathrm{kg}$ of soybean input per annum was the basis for estimating different investment years and scales.

In different investment years, the total capital investment has increased from the 1980s to the 2010s, following the growth of the economy and thus the inflation index. Because of the increasing demands for food, feed and fuel applications, the success of the U.S. RFS (renewable fuel standard program) and the RIN (renewable identification number) markets, many U.S. companies began expansion plans in recent years [40]. In our simulations, the processing capacity was increased using 6 scenarios. The largest scale was 2991.93 million kg soybean input per annum, which was similar to that of the Landus Cooperative soybean expelling plant in Ralston, IA, USA. The relationship between total capital investment and the various scales is illustrated in Figure 3.

A power relationship ( $\mathrm{n}$ ) of 0.42 between total capital investment and annual soybean input is clearly seen in the results. This relationship is expressed in Equation (7), where ' $X$ ' was the annual soybean input (million $\mathrm{kg}$ ) and ' $\mathrm{y}$ ' was the estimated total capital investment. Additionally, compared to the hexane extraction process [41], the extruding-expelling process has lower fixed capital investment than the hexane extraction process. This result suggests that the mechanical pressing technology is a less complex process.

$$
y=10186.01 X^{0.42}
$$




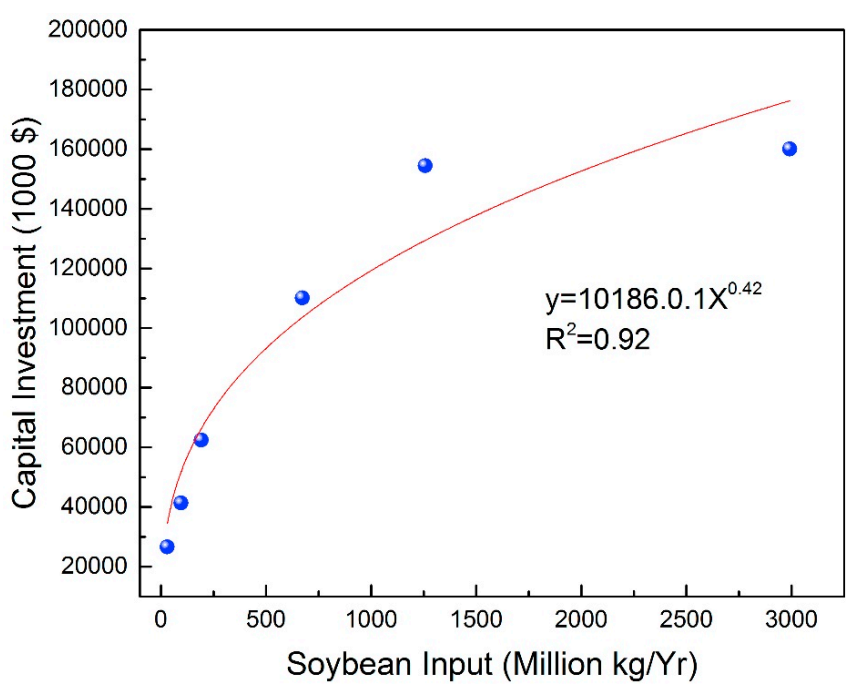

Figure 3. Non-linear relationship between total capital investment and various soybean input scales (i.e., processing capacities).

\subsection{Operating Costs}

Operating costs are critical for estimating the profit of the extruding-expelling system. Operating costs may change with fluctuations in economic conditions. Therefore, the impact of changes in materials, utility, labor, and facility-related costs on total operating cost are illustrated in Figure 4.

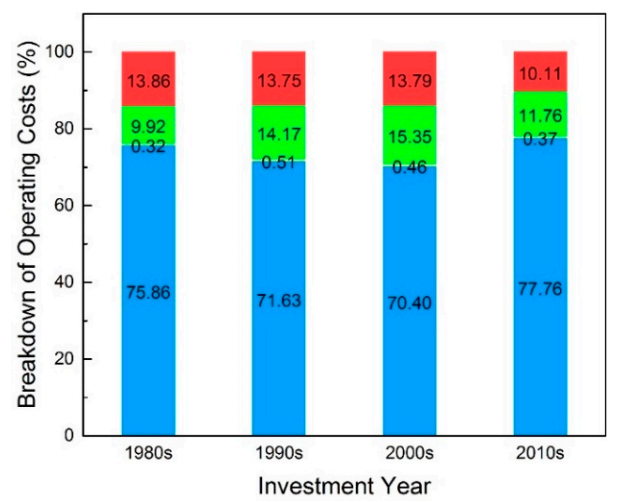

(a)

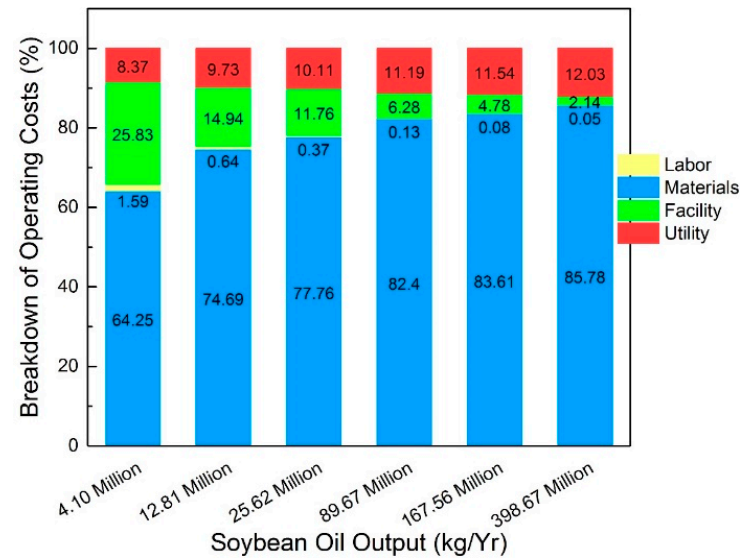

(b)

Figure 4. Breakdown of operating costs. (a) 1980-2015 data; (b) Different scales of oil expelling based on 2010s inputs only. 


\subsubsection{Material Costs}

Soybean, water, and phosphoric acid are the major sources of material costs; soybean cost accounts for over $98 \%$ of the total material cost. In contrast, water and phosphoric acid are only used in the degumming process; therefore, only small amounts are needed for operation. Therefore, they comprise less than $1 \%$ of the total material costs.

From Figure 4a, the majority of total operating costs increased over $70 \%$ from the 1980 s to the 2010s. The fluctuation of the cost of materials illustrates the changes of market conditions (primarily soybean prices). From the 1980s to the 2010s, material cost has increased about $91 \%$, which caused a portion of material costs to reach to about $78 \%$ of total costs in the 2010 s.

From Figure $4 \mathrm{~b}$, the portion of material cost in total operating costs has increased when the plant processing capacity increased in scale. Materials account for $\sim 64 \%$ of total operating costs for a facility producing 4.10 million $\mathrm{kg}$ oil production per annum; and account for over $85 \%$ for the largest scale facilities. This result also indicates the extruding-expelling process is a material intense process because material costs make up the majority of all costs in all scales.

\subsubsection{Utility Costs}

Utility costs include the electricity used to operate machines and steam and cooling used as heat exchange agents. From Figure $4 a$, utility cost portion accounts for $10 \%$ of total operating costs from the 1980 s to the 2010s. However, utility costs increased about $40 \%$ during that time, which is much less than material costs increasing over $90 \%$. This result shows utility costs decreased from the 1980 s to the 2010s.

According to Figure $4 \mathrm{~b}$, when the scale of plant capacity increases, the percentage of utility costs increase. Compared to the hexane extraction process [35], the large portion of utility costs are observed in the similar capacity of extruding-expelling process. Additionally, the utility cost portion from electricity accounts for $90 \%$ of all utility costs in all scenarios. This result shows the extruding-expelling process is a high, electricity demanding technique in an oil production process.

\subsubsection{Facility and Labor Related Costs}

Facility-related costs mainly arise from machine maintenance fees; whereas labor costs include machine operation and laboratory QA/QC costs.

Figure 4 a shows facility related costs take up $9-15 \%$ of total operating costs. Based on the inflation index, facility related cost increased from the 1980 s to the 2000 s by about $20 \%$; which means the percentage of facility related costs increased over $14 \%$ in the 1990s and 2000s. However, it decreased to about $10 \%$ in the 2010 s because material cost increased over $55 \%$ from the 2000 s to recent years. Facility related costs have only increased around $20 \%$ from the 2000 s.

Based on Figure $4 \mathrm{~b}$, the percentages of facility and labor related costs decreased when plant capacity scale increased. This was because more materials and higher utility costs are required in larger scales operations. Though a larger scale facility leads to higher maintenance fees, they still make up a small portion of the total operating cost.

As to labor costs, it takes up the smallest percentage of total operating costs. The breakdown of labor costs is shown in Figure 5. According to Figure 5a, results demonstrate that the wage of an extraction worker has increased more than that of an agricultural machine worker for the last three decades. For different plant capacities, the cost of an agricultural machine worker increases when the capacity increases in scale. This also indicates more agricultural machine workers are needed for dealing with crop-handling process. These results indicate the extruding-expelling process is an agricultural machine-intense process vis-à-vis the characteristics of the extraction process (Figure 5b), as the labor requirement shifts toward more ag machine labor as production scale increases. 


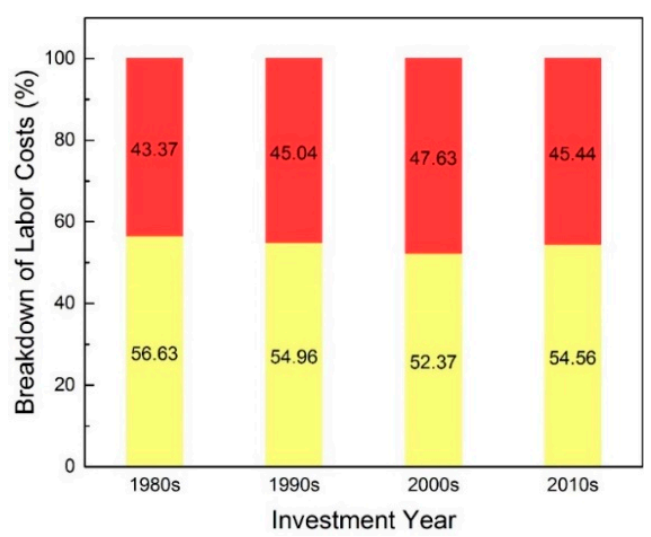

(a)

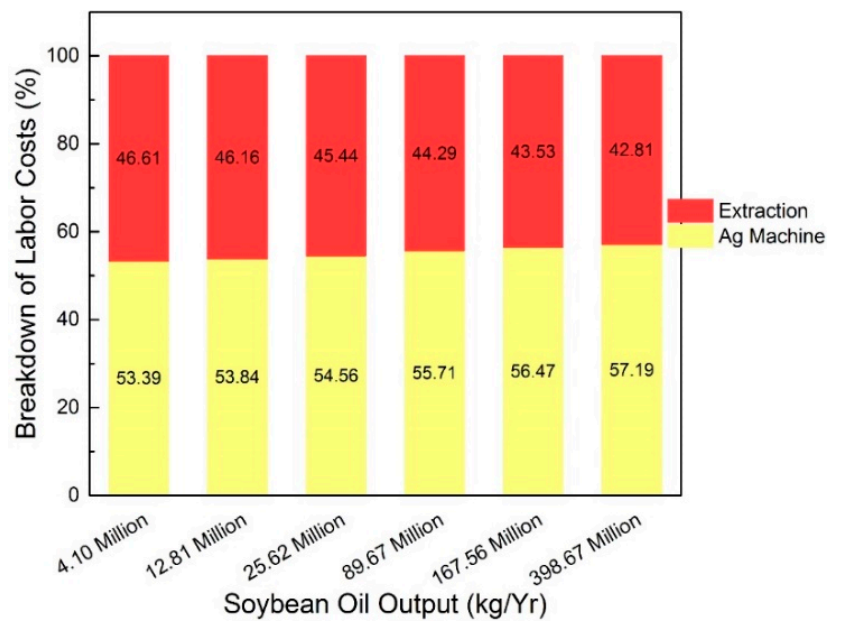

(b)

Figure 5. Labor costs. (a) 1980-2015 data; (b) Various scales of oil production.

\subsubsection{Unit Production Cost}

The unit production cost was calculated by dividing the total annual operating cost by the annual soybean oil productivity (output). Based on the baseline scale, between the 1980s to the 2010s the unit production cost of soybean oil production has increased from $\$ 2.26$ to $\$ 4.23$ per $\mathrm{kg}$ because of the changes in the market conditions.

The effect of different plant capacities is shown in Figure 6. From these results, the unit production cost has decreased from $\$ 5.12$ to $\$ 3.80$ per $\mathrm{kg}$ of soybean oil when the facility capacity increased in scale. Moreover, the higher unit production cost than the hexane extraction process ( $\$ 3.04$ to $\$ 1.60$ per $1 \mathrm{~kg}$ of soybean oil) is observed in similar plant capacities due to its lower oil yields. ${ }^{41}$ Additionally, we observed a power relationship of -0.07 between unit production cost and soybean oil output.

The unit operating cost (Figure 7) was calculated by dividing total annual operating cost by annual soybean input. A similar trend was observed with unit production cost, resulting in a -0.07 power relationship between unit operating cost and the various plant capacities. The unit operating cost decreased from $\$ 0.68$ to $\$ 0.51$ per $\mathrm{kg}$ soybean input per annum when the capacity increased from smallest to largest capacity. 


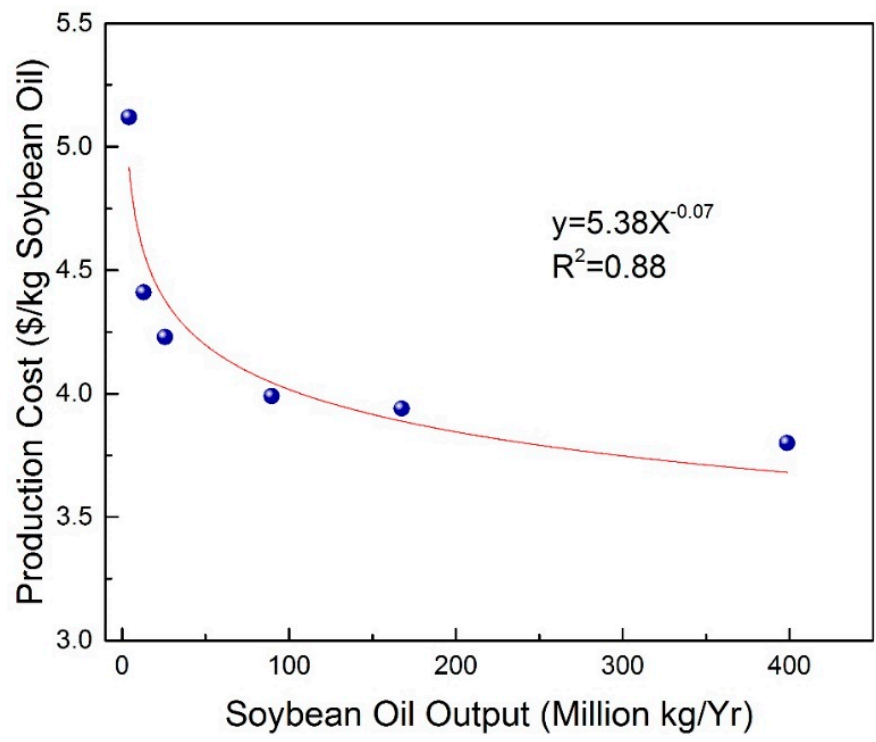

Figure 6. Non-linear relationship between net unit production cost and various scales of soybean oil production (outputs).

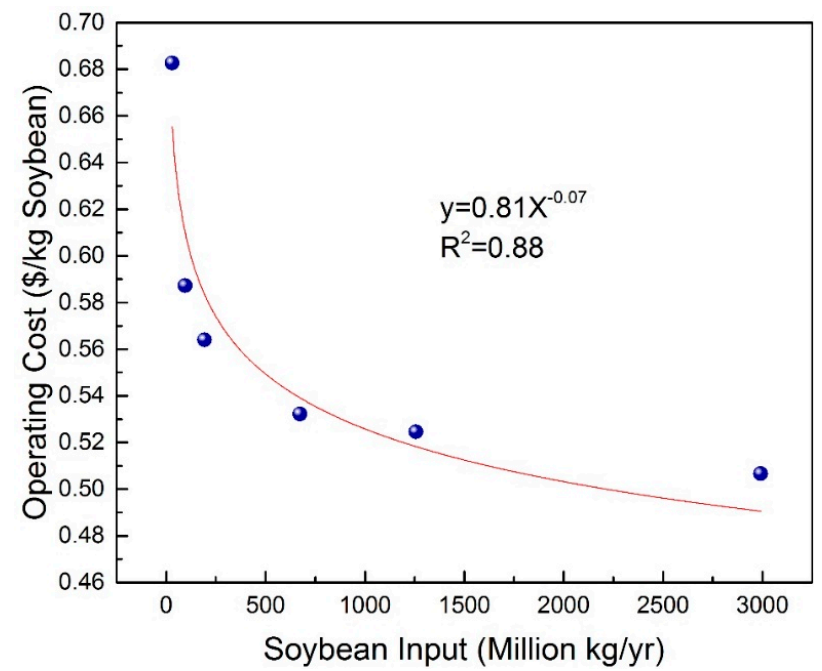

Figure 7. Non-linear relationship between net unit operating cost and various scales of soybean inputs (i.e., processing capacities).

\subsection{Revenues and Profits}

Degummed crude soybean oil and soybean meal are the main products of the extruding-expelling process. The annual revenues, gross profits, and net profits are illustrated in Figure 8.

Based on the productivities of soybean oil and soybean meal, revenues from soybean oil and soybean meal are $\sim 23 \%$ and $\sim 77 \%$ respectively. Though the oil expelling process is used to produce oil, the soybean meal is actually the driving force for the whole production system.

From Figure $8 \mathrm{a}$, the increasing economic and markets can be also impacted. The extruding-expelling process has positive gross and net profits, indicating this process was profitable. The effect of different plant capacities shows (Figure $8 b$ ), all parameters increased when the capacity was scaled up. A plant producing 4.10 million $\mathrm{kg}$ of soybean oil annually, with a negative gross profit, can have a positive net profit when the depreciation was considered. Additionally, a positive gross profit can be obtained when the capacity was larger than 12.81 million kg soybean oil output per annum, which indicates the break-even point of the extrusion-expelling process was between the capacity of 30.77 and 96.14 million annual soybean input. 


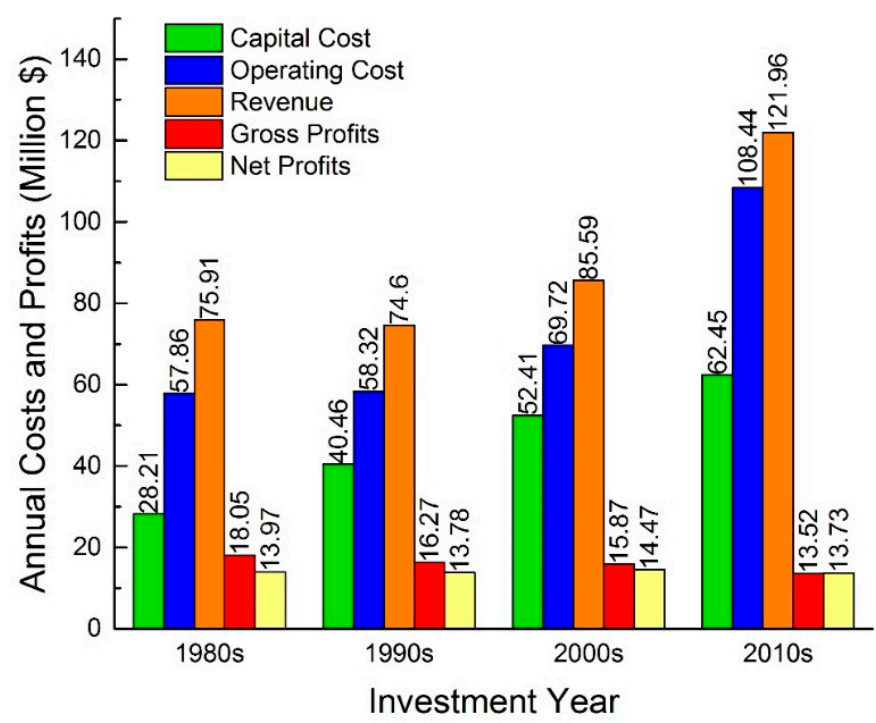

(a)

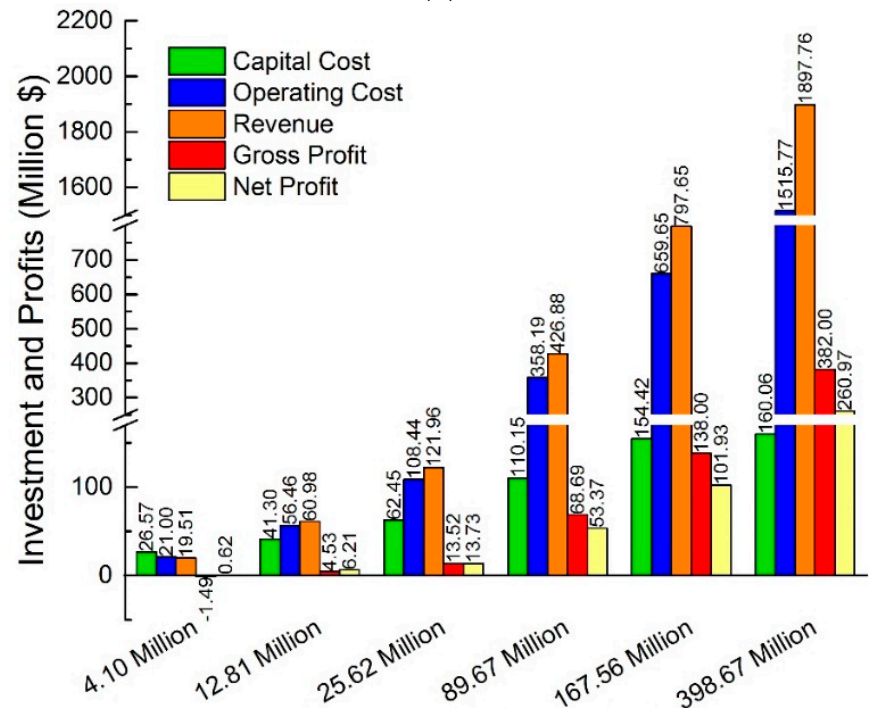

Soybean Oil Output $(\mathrm{kg} / \mathrm{Yr})$

(b)

Figure 8. Capital investment, gross and net profits for soybean oil extruding-expelling. (a) 1980-2015 data; (b) Various scales of oil production (2010s input only).

According to ROI, payback time can be calculated following the Equation (8). The economic feasibility of the process was determined by gross margin and payback time. The results are shown in Table 7. From gross margin results, positive values are observed when the capacity was larger than 30.77 million $\mathrm{kg}$ soybean input per annum. Though the capacity of the 30.77 million kg soybean input per annum has a positive ROI; however, the payback time was longer than the service time (15 years) of this project. Therefore, this scale can't be regarded as a profitable and economically feasible process. Conclusively, a process with a positive gross margin and a payback time shorter than service time was considered a profitable process. Thus, when the capacity of the extruding-expelling process has a capacity larger than 30.77 million $\mathrm{kg}$ soybean input per annum, it can be a profitable and economically feasible process.

$$
\text { Payback Time }=\frac{100}{\mathrm{ROI}}
$$


Table 7. Gross margin, ROI, and payback time of various soybean oil production scales.

\begin{tabular}{ccccccc}
\hline & \multicolumn{6}{c}{ Soybean Annual Input (Million Kg) } \\
\cline { 2 - 7 } & $\mathbf{3 0 . 7 7}$ & $\mathbf{9 6 . 1 4}$ & $\mathbf{1 9 2 . 2 8}$ & $\mathbf{6 7 2 . 9 9}$ & $\mathbf{1 2 5 7 . 5 3}$ & $\mathbf{2 9 9 1 . 9 3}$ \\
\hline Gross Margin (\%) & -7.62 & 7.42 & 11.09 & 16.09 & 17.30 & 20.13 \\
ROI (\%) & 2.32 & 15.04 & 21.99 & 48.45 & 66.01 & 163.04 \\
Payback Time (yr) & 43.14 & 6.65 & 4.55 & 2.06 & 1.52 & 0.61 \\
\hline
\end{tabular}

\subsection{Sensitivity Analysis}

According to the results of net profit and payback time, the extruding-expelling process has a high potential to be economically feasible. The annual soybean inputs of $96.14,672.99$, and 2991.93 million $\mathrm{kg}$, which have 12.81, 89.67, and 398.67 million kg soybean oil output per annum, are chosen for the sensitivity analysis. Sensitivity analysis examines which factor included in operating costs and revenues has the most significant effect on net profit when the cost and sales price fluctuate with economic and market conditions. The results are shown in Figure 9. When operating costs (including material, labor, and utilities) increase, the net profit decreases, which is shown in the negative bar (yellow bar) and vice versa. Net profit changes with changes in operating costs and retail prices of $\pm 5 \%, \pm 15 \%$ and $\pm 25 \%$. The increase in operating costs typically results in net profit decreases, and vice versa, as shown in Figure 9a for12.81 million kg soybean oil production per annum, Figure $9 \mathrm{~b}$ for 89.67 million $\mathrm{kg}$ soybean oil production per annum, and Figure 9c for 398.67 million $\mathrm{kg}$ soybean oil production per annum. As shown, production scale impacted the results.

From the results, the larger range of change in operating costs and sales prices leads to larger changes in net profits. In these three scales, soybean meal has the most remarkable effect on the net profit in all levels of price changes, followed by soybeans and then soybean oil. This indicates soybean meal plays an important role in the process and was seen as the driving force for the extruding-expelling technique used in the industry. Additionally, as the scale of capacity increases, the level changes of net profit caused by price changes decreases.

In the aspect of operating costs, soybeans and electricity are the two factors that have the most obvious effect on net profit changes. This also demonstrates the property of a mechanical process. However, as the capacity was scaled up, more energy demands are required for the production stream; especially when cooling water, which cools down the system after heat was generated from extruding process. Therefore, the effect of cooling water exceeds the labor cost, and follows electricity cost when the capacity was scaled up. Additionally, higher amounts of phosphoric acid are required in the degumming process for a larger plant size. The effect of phosphoric acid cost exceeds the labor cost at the largest operating scale. This result corresponds to the previous discussion about the portions of each operating cost.

Overall, extruding-expelling is a product-leading process; especially the revenue from soybean meal. However, the material cost from soybeans still plays a critical role in determining the profit of the whole process. These results show the uniqueness of the extruding-expelling process; which still exists in the industry even though solvent extraction is more often used due to its higher separation efficiency. 

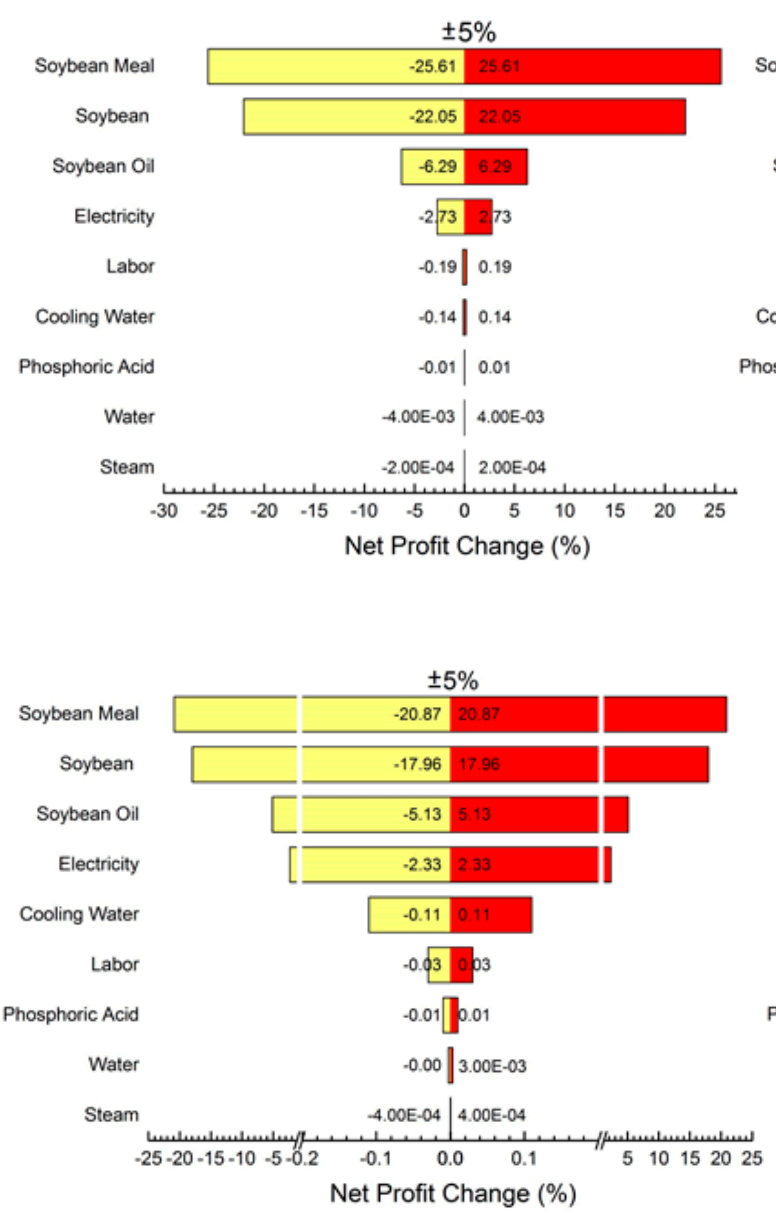

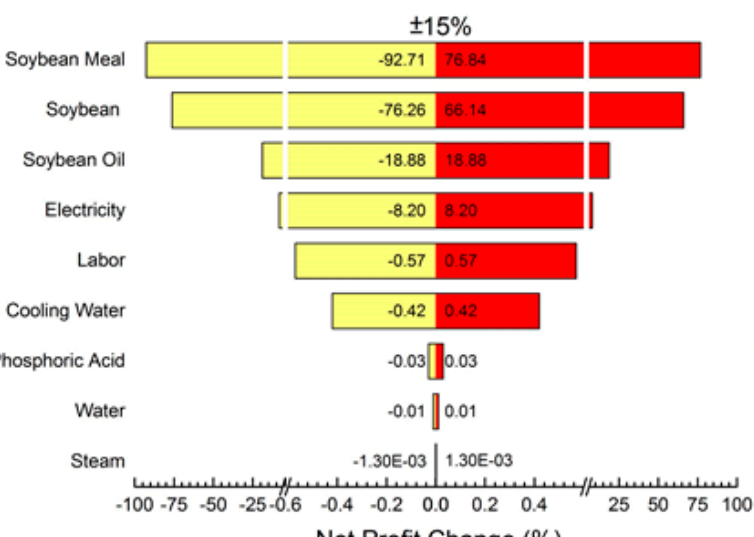

Net Profit Change (\%)

(a)

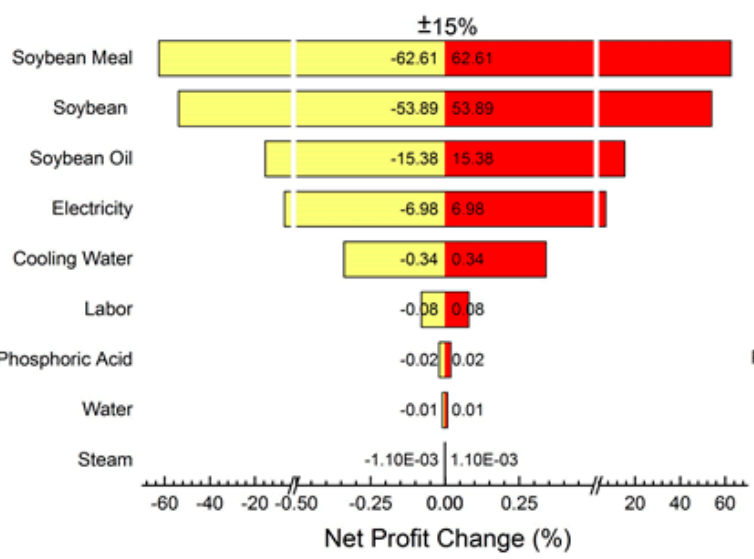

(b)
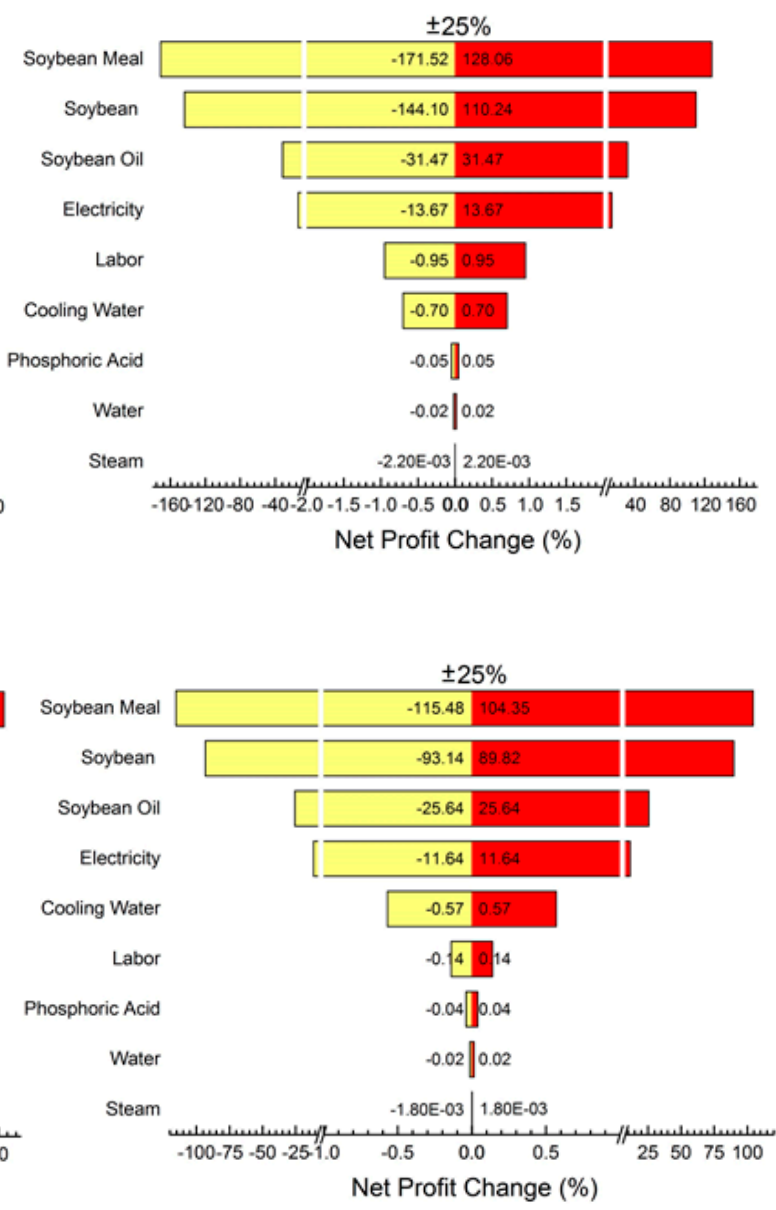

Figure 9. Cont. 


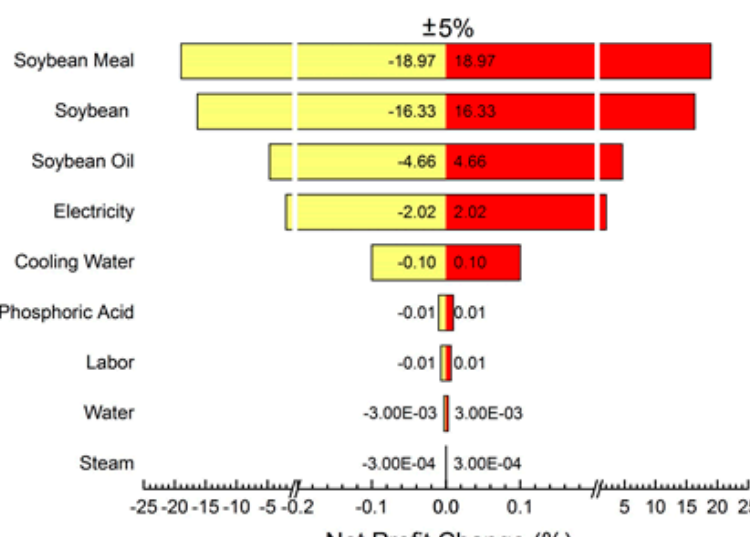

Net Profit Change (\%)

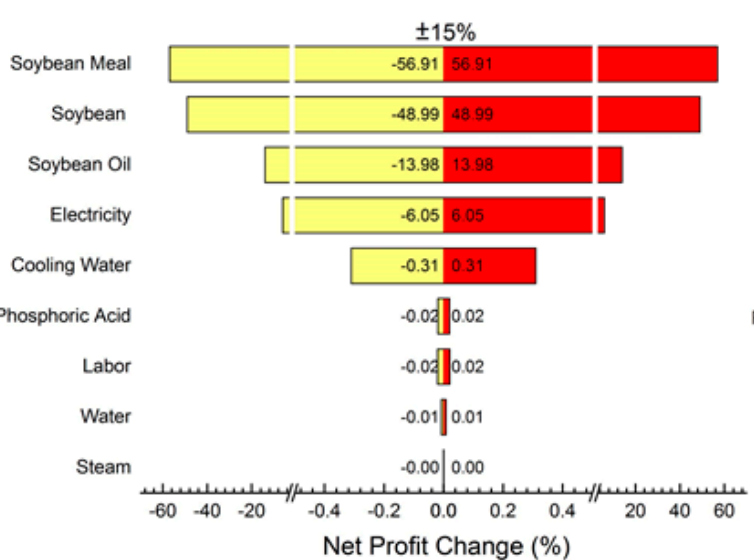

(c)

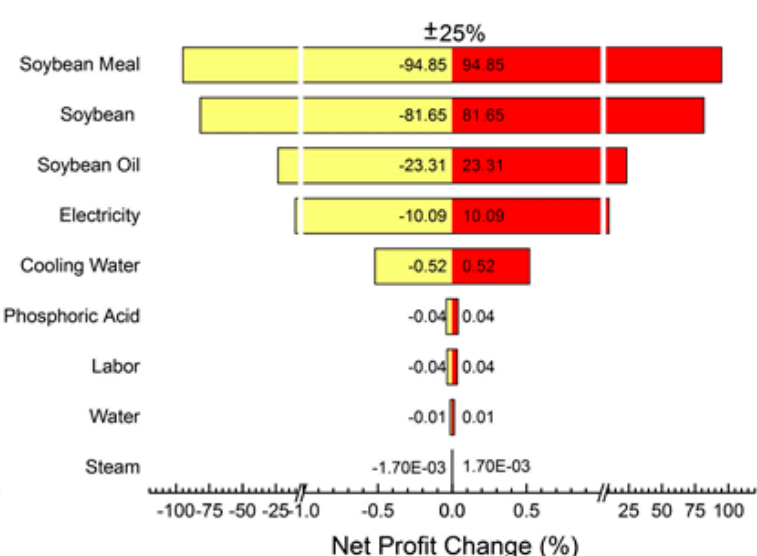

Net Profit Change $(\%)$

Figure 9. Net profit changes with changes in operating costs and retail prices of $\pm 5 \%, \pm 15 \%$ and $\pm 25 \%$. The increase in operating costs typically results in net profit decreases, and vice versa. (a) 12.81 million kg soybean oil production per annum; (b) 89.67 million $\mathrm{kg}$ soybean oil production per annum; (c) 398.67 million kg soybean oil production per annum. 


\section{Conclusions}

Mechanical expelling is a technique used to extract oil from crops using heat and pressure. The extruding-expelling process simplifies the expelling process and increases the efficiency of the whole process. Not only does it lower the total capital investment, but also reduces operating costs compared to the traditional expelling process. According to our results, the extruding-expelling process is an economically feasible technique when the plant capacity is larger than $\sim 30.77$ million $\mathrm{kg}$ soybean input per annum. Moreover, soybean meal is the driving force for the whole process because it provides over $70 \%$ of the total revenue for soy processing by expelling. Additionally, higher revenues for expelled soybean meal are the main reasons for higher revenue due to its higher oil content, and thus higher energy content. This is also the reason why the mechanical expelling process still exists for specific feed applications.

Author Contributions: K.R. conceive the work; M.-H.C. built the models, ran the simulations, analyzed the data, and drafted the paper; K.R. edited the models and simulations, verified and edited the results, and edited the paper.

Funding: This research was funded by the United States Department of Agriculture.

Acknowledgments: The authors would like to thank the USDA for providing funding for this work, and Iowa State University for use of equipment and facilities.

Conflicts of Interest: The authors declare no conflict of interest.

\section{References}

1. SoyStat. U.S. Yield and Production: Production by State. 2015. Available online: http://soystats.com/u-syield-production-production-by-state/ (accessed on 3 January 2016).

2. SoyStats. 2015 Soy Hightlights. 2015. Available online: http://soystats.com/2013-highlights/ (accessed on 3 January 2016).

3. Lynch, G.; Berger, L.; Merchen, N.; Fahey, G.; Baker, E. Effects of heat and alcohol treatments of soybean meal on nitrogen utilization by sheep. J. Anim. Sci. 1987, 65, 235-243. [CrossRef] [PubMed]

4. Corley, R.; Woldeghebriel, A.; Corley, M.; Murphy, M. Effect of ethanol concentration and application period of soybean meal on the kinetics of ruminal digestion. Anim. Feed Sci. Technol. 1999, 79, 247-254. [CrossRef]

5. Sawada, M.; Venâncio, L.; Toda, T.; Rodrigues, C. Effects of different alcoholic extraction conditions on soybean oil yield, fatty acid composition and protein solubility of defatted meal. Food Res. Int. 2014, 62, 662-670. [CrossRef]

6. Ma, F.; Hanna, M. Biodiesel production: A review. Bioresour. Technol. 1999, 70, 1-15. [CrossRef]

7. Erhan, S.; Asadauskas, S. Lubricant basestocks from vegetable oils. Ind. Crop. Prod. 2000, 11, $277-282$. [CrossRef]

8. Cheng, Z.; Hardy, R. Effects of extrusion and expelling processing, and microbial phytase supplementation on apparent digestibility coefficients of nutrients in full-fat soybeans for rainbow trout (Oncorhynchus mykiss). Aquaculture 2003, 218, 501-514. [CrossRef]

9. Nelson, A.; Wijeratne, W.; Yeh, S.; Wei, T.; Wei, L. Dry extrusion as an aid to mechanical expelling of oil from soybeans. J. Am. Oil Chem. Soc. 1987, 64, 1341-1347. [CrossRef]

10. Li, H.; Pordesimo, L.; Weiss, J. High intensity ultrasound-assisted extraction of oil from soybeans. Food Res. Int. 2004, 37, 731-738. [CrossRef]

11. Oliveira, R.; Barros, S.; Gimenes, M. The extraction of passion fruit oil with green solvent. J. Food Eng. 2013, 117, 458-463. [CrossRef]

12. Erickson, D. Overview of modern soybean processing and links between processes. In Practical Handbook of Soybean Processing and Utilization; Erickson, D., Ed.; AOCS Press: St. Louis, MO, USA, 1995; pp. 56-64.

13. Bargela, P.; Ford, R.; Sosulski, F.; Wulfsohn, D.; Irudayaraj, J. Mechanical oil expression from extruded soybean samples. J. Am. Oil Chem. Soc. 1999, 76, 223-229. [CrossRef]

14. Patil, R.; Ali, N. Effect of pre-treatments on mechanical oil expression of soybean using a commercial oil expeller. Int. J. Food Prop. 2006, 9, 227-236. [CrossRef] 
15. Subroto, E.; Manurung, R.; Heeres, H.; Broekhuis, A. Mechanical extraction of oil from latropha curcas L. kernel: Effect of processing parameters. Ind. Crop. Prod. 2015, 63, 303-310. [CrossRef]

16. Nelson, R.; Howell, S.; Weber, J. Potential feedstock supply and costs for biodiesel production. In Proceedings of the Sixth National Bioenergy Conference, Reno, NV, USA, 2-6 October 1994.

17. Haas, M.; McAloon, A.; Yee, W.; Foglia, T. A process model to estimate biodiesel production costs. Bioresour. Technol. 2006, 97, 671-678. [CrossRef] [PubMed]

18. Marchetti, J.; Miguel, V.; Errazu, A. Techno-economic study of different alternatives for biodiesel production. Fuel Process. Technol. 2008, 89, 740-748. [CrossRef]

19. Fore, S.; Lazarus, W.; Porter, P.; Jordan, N. Economics of small-scale on-farm use of canola and soybean for biodiesel and straight plant oil biofuels. Biomass Bioenergy 2011, 35, 193-202. [CrossRef]

20. Nevase, S.; Gadge, S.; Dubey, A.; Kadu, B. Economics of biodiesel production from Jatropha oil. J. Agric. Technol. 2012, 8, 657-662.

21. Illupitiya, P.; de Koff, J. Economics of Small-Scale Biodiesel Production; College of Agriculture, Human and Natural Science Cooperative Extension, Tennessee State University: Nashville, TN, USA, 2014; Publication TSU-14-0117(A)-7e-17095; Available online: http://www.tnstate.edu/extension/documents/ BiodieselEconomics.pdf (accessed on 25 February 2019).

22. Mupondwa, E.; Li, X.; Falk, K.; Gugel, R.; Tabil, L. Technoeconomic analysis of small-scale farmer-owned camelina oil extraction as feedstock for biodiesel production: A case study in the Canada prairies. Ind. Crop. Prod. 2016, 90, 76-86. [CrossRef]

23. White, N.; Callahan, C. Vermont On-Farm Oilseed Enterprises: Production Capacity and Breakeven Economics. 2013. Available online: http://vermontbioenergy.com/wp-content/uploads/2013/03/VT-OilseedEnterprises_July_2013.pdf (accessed on 25 February 2019).

24. Grubinger, V. On-Farm Oil Seed Production and Processing; The University of Vermont Extension: Burlington, VT, Canada, 2007; Available online: https:/www.uvm.edu/vtvegandberry/Pubs/Final\%20Report\%205-152007.pdf (accessed on 25 February 2019).

25. Bender, M. Economic feasibility review for community-scale farmer cooperatives for biodiesel. Bioresour. Technol. 1999, 70, 81-87. [CrossRef]

26. Zhang, Y.; Dubé, M.; McLean, D.; Kates, M. Biodiesel production from waste cooking oil: 2 economic assessment and sensitivity analysis. Bioresour. Technol. 2003, 90, 229-240. [CrossRef]

27. Mlay, H.; Katima, J.; Minja, R. Modifying plant oils for use as fuel in rural contexts Tanzania: Techno-economic analysis. Open J. Model. Simul. 2014, 2, 43-56. [CrossRef]

28. Dijkstra, A. Edible Oil Processing: Introduction to Degumming. 2019. Available online: http://lipidlibrary. aocs.org/OilsFats/content.cfm?ItemNumber=40325 (accessed on 25 February 2019).

29. Deffense, E. Chemical Degumming. 2019. Available online: http://lipidlibrary.aocs.org/OilsFats/content.cfm? ItemNumber $=40322$ (accessed on 25 February 2019).

30. Ngo, H.; Yee, W.; McAloon, A.; Haas, M. Techno-economic analysis of an improved process for producing saturated branched-chain fatty acids. J. Agric. Sci. 2014, 6, 158-168. [CrossRef]

31. Heinzle, E.; Biwer, A.; Cooney, C. Sustainability assessment. In Development of Sustainable Bioprocesses: Modeling and Assessment; Heinzle, E., Biwer, A., Cooney, C., Eds.; John Wiley \& Sons Ltd.: West Sussex, UK, 2006; pp. 81-117.

32. US BLS. CPI Inflation Calculator. 2016. Available online: https://www.bls.gov/data/inflation_calculator.htm/ (accessed on 10 November 2016).

33. Ulrich, G. (Ed.) Capital cost estimation. In A Guide to Chemical Engineering Process Design and Economics; John Wiley \& Sons, Inc.: New York, NY, USA, 1984; pp. 265-323.

34. Peters, M.; Timmerhaus, K.; West, R. (Eds.) Analysis of cost estimation. In Plant Designer and Economics for Chemical Engineers; McGraw Hill: New York, NY, USA, 2011; pp. 226-278.

35. SuperPro Designer. SuperPro Designer Equipment Database; Intelligen Inc.: Scotch Plains, NJ, USA, 2015.

36. USDA ERS. Oil Crops Yearbook. 2016. Available online: https://www.ers.usda.gov/data-products/oil-cropsyearbook/ (accessed on 25 February 2019).

37. City of Ames. Rates and Structure. 2016. Available online: http://www.cityofames.org/government/ departments-divisions-i-z/water-pollution-control/rates-and-structure/ (accessed on 10 November 2016).

38. US EIA. Electricity Data. 2016. Available online: http://www.eia.gov/electricity/data.cfm/ (accessed on 10 November 2016). 
39. US BLS. Occupational Employment Statistics. 2016. Available online: http://www.bls.gov/oes/tables.htm/ (accessed on 10 November 2016).

40. Biodiesel Magazine. USA Plants. 2015. Available online: http://www.biodieselmagazine.com/plants/ listplants/USA/ (accessed on 15 November 2016).

41. Cheng, M.H.; Rosentrater, K.A. Economic reasibility analysis of soybean oil production by hexane extraction. Ind. Crop. Prod. 2017, 108, 775-785. [CrossRef]

(c) (1)

(C) 2019 by the authors. Licensee MDPI, Basel, Switzerland. This article is an open access article distributed under the terms and conditions of the Creative Commons Attribution (CC BY) license (http://creativecommons.org/licenses/by/4.0/). 